\title{
RECIPROCAL EXEMPTION PROVISIONS OF WORKMEN'S COMPENSATION ACTS
}

\author{
FREDERIC P. STORKE $\dagger$ \\ DON W. SEARS $+\dagger$
}

Soon after the first workmen's compensation acts were passed, courts were forced to consider the extraterritorial application of the statutes. The problem is still troublesome. In the most commonly recurring situation, a worker employed in one state is injured while working temporarily in another. Should the compensation act of the state of injury be applied or the act of the state of employment or both or neither? The efforts of courts to answer the question of applicable law have produced a bewildering variety of results and a great confusion of theoretical approaches. More recently, reciprocal exemption statutes have been enacted in an attempt to introduce some measure of order into this disorderly field, by giving employer and employees a more definite idea of their respective rights and duties.

\section{The "Chotce-of-LAw" Problem}

The extraterritorial application of compensation acts is not a choice-of-law problem in the traditional sense. In other fields of conflict of laws, such as tort or contract, the underlying assumption is that the law of one state applies to the exclusion of the other. The forum looks for a choice-of-law rule that will direct it to the internal law of one of the two or more states which have contacts with the case. This internal law will then be applied whether it is the law of the forum or of some other state. ${ }^{1}$ In the workmen's compensation area, nearly all courts follow a different approach. For practical reasons, the forum does not apply the compensation act of any other state. It either applies its own compensation act or dismisses the case. ${ }^{2}$

Despite this specialized treatment, the analysis of many compensation cases follows the classic choice-of-law pattern. Thus, courts often classify the case

$\dagger$ Professor of Law, University of Colorado School of Law.

††Professor of Law, University of Colorado School of Law.

1. The standard process is described in detail in Hogan, Constitutional Implications of Workmen's Compensation and Choice of Law, 7 Hastings L.J. 268 (1956), crediting the analysis to Professor Lorenzen. See also Robertson, Characterization in the Conflict of Laws c. 1 (1940).

2. See Mosely v. Empire Gas \& Fuel Co., 313 Mo. 225, 281 S.W. 762 (1926) ; MAThews, The Employment Relation and the Law 338 (1957); Stumberg, Conflict of Laws 223 (2d ed. 1951) ; 2 LARson, WorkMEN's Compensation LAW \$ 84.20 (1952) (hereinafter cited as LarsoN). A few statutes prescribe an opposite view. See, e.g., Artz. Code AnN. § 23-904 (Supp. 1954); Hawair Rev. Laws § 97-8 (1955); Idaho Code Ann. § $72-615$ (Supp. 1957); VT. Stat. $\S 8074$ (1947). And Mississippi has enforced the Louisiana compensation act in the absence of statute. 
according to certain accepted categories and find the appropriate connecting factor which fits the category selected. Most likely, this method stems from the original assumption that compensation cases could be fitted into one of the recognized categories, either tort or contract. If tort were chosen, the connecting factor would be the locus of the injury. ${ }^{3}$ The compensation act of the state of injury, and no other, would govern the case. If the contract category were selected, greater flexibility was possible. The court might use either the place the contract was made or the place of performance, or whichever of these was chosen by the parties as the connecting factor.4

But the unsatisfactory nature of either the contract or tort approach soon became apparent." Liability for compensation depends upon a combination of the employment status, created by contract, and the occurrence of an injury, not necessarily the result of any fault of the employer. On theoretical grounds, the treatment of compensation cases as either tort or contract is therefore unsound. Exclusive classification is also practically undesirable because it limits too narrowly the application of the statute. If the state of injury were to adopt the contract approach and the state of the contract were to adhere to the tort approach, neither statute would apply and the claimant would go uncompensated.

To remedy this situation, courts developed the idea that workmen's compensation cases should be placed in a category of their own, and a new connecting factor applied to this category. In Val Blatz Brewing Co. v. Industrial Comm'n," the connecting factor was said to be the location of the "employment status." So long as this status was located in Wisconsin, the compensation act of that state would apply, even though the injury occurred, and all of the employee's services were to be rendered, outside the state. The location of the employment status, however, contributes little or nothing to a solution of the problem. It only provides another example of what has been called "reification"- the vice of treating an abstract legal relationship as a physical object and then attempting to locate that object in space. Of course, a status does not actually exist in any particular spot. Under the cover of this facile verbalization, the courts are actually looking at the various contacts which a workmen's compensation case has with the forum and deciding which particular contacts or combination of contacts will justify the exercise of legislative jurisdiction. ${ }^{7}$

3. Gould's Case, 215 Mass. 480, 102 N.E. 693 (1913); 2 Larson $\S 87.21$. The rule of the Gould case was changed by statute in Massachusetts. MAss. ANN. LAws c. 152, § $26 \mathrm{~B}$ (Supp. 1957). 1957).

4. Cheathas, Goodrich, Griswold \& Reese, Conflict of Laws 476 n.2 (4th ed.

5. Val Blatz Brewing Co. v. Industrial Comm'n, 201 Wis. 474, 230 N.W. 622 (1930).

6. Ibid.

7. See Quong Ham Wah Co. v. Industrial Acc. Comm'n, 184 Cal. 26, 192 Pac. 1021 (1920) ; Smith v. Heine Safety Boiler Co., 224 N.Y. 9, 119 N.E. 878 (1918) ; Fay v. Industrial Comm'n, 100 Utah 542, 114 P.2d 508 (1941); Perfect Seal Rock Wool Mfg. Co. v. Industrial Comm'n, 257 Wis. 133, 42 N.W.2d 449 (1950); Val Blatz Brewing 
Regardless of theory, the actual process used by the courts is best described as the multiplication-of-contacts method. ${ }^{8}$ In the Val Blatz case, the result was based on a feeling that the combination of domicile, place of making of the contract and principle focus of the employer's activities furnished a sufficient basis for the application of the Wisconsin compensation act, although all of the employee's services were to be rendered outside that state and the injury also occurred outside the forum. More generally, the contacts usually considered important are the place of injury, the place of maling of the contract, the place where the services are to be performed, the principal focus of the employer's activities and the domicile of the employee. ${ }^{9}$ Furthermore, if the parties designate a state law to govern the liability of the employer. this designation is sometimes regarded as an additional contact point and may be determinative. ${ }^{10}$

Probably no two states agree exactly about the combination of contacts to be used. One possible view is that the local statute will apply when any one of these contact points is present, but no state seems to have gone this far. In some states, jurisdiction may exist when a specific single contact exists, such as the locus of the injury or the place of making of the contract. Many of the decisions, however, emphasize the presence of two or more of these contact points. ${ }^{11}$

\section{Constitutional Limitations}

In applying their own workmen's compensation acts, state courts are confronted with important constitutional restrictions on legislative jurisdiction which have long been taken for granted. The interstate commerce clause, ${ }^{12}$ for example, clearly prevents a state from extending its compensation act into that part of the commerce field which Congress has pre-empted. Workers on interstate railroads, ${ }^{13}$ seamen, ${ }^{14}$ harbor workers and longshoremen ${ }^{15}$ are among those employees whose coverage under state statutes is curtailed. So far, Congress has not acted with respect to employees of interstate bus lines ${ }^{16}$

Co. v. Industrial Comm'n, 201 Wis. 474, 230 N.W. 622 (1930). Larson favors this test but concedes the difficulties in its application. 2 LARSON $\$ 87.41$.

8. Cowan, Extraterritorial Application of Workmen's Compensation Laws-A Suggested Solution, 33 TexAs L. REV. 917 (1955).

9. See ibid.

10. Ehrenzweig, Adhesion Contracts in the Conflict of Lawes, 53 Colum. L. Rev. 1072 (1953), takes the position that the law chosen by the parties should be given effect only in the case of negotiated contracts.

11. In Daniels v. Trailer Transp. Co., 327 Mich. 525, 42 N.W.2d 828 (1950), five different states had contacts with the case.

12. U.S. Consr. art. I, § 8, cl. 3.

13. Federal Employers' Liability Act, 35 Stat. 65 (1908), as amended, 45 U.S.C. $\$ \$ 51-60$ (1952).

14. Merchant Marine Act, 1920 (Jones Act), 41 STAT. 1007, 46 U.S.C. $\$ 688$ (1952).

15. Longshoremen's and Harbor Workers' Compensation Act, 44 STAr. 1424 (1.927), as amended, 33 U.S.C. $\$ \$ 901-50$ (1952).

16. See Collins v. American Buslines, Inc., 350 U.S. 528 (1956). 
or airlines, ${ }^{17}$ so that a state, if it chooses, may apply its own compensation act.

For present purposes, the important provisions of the Constitution are the due process ${ }^{18}$ and full faith and credit clauses. ${ }^{19}$ In spite of the extensive discussions of this matter, the United States Supreme Court has never held directly that a state may not apply its own workmen's compensation act in a conflicts situation. In the key case, Bradford Elec. Light Co. v. Clapper, ${ }^{20}$ the Supreme Court merely held that the state of injury could not apply its statutory tort law because to do so would deny full faith and credit to a provision of the state with the dominant contacts that the remedy under its workmen's compensation act should be exclusive. Admittedly, the case reasonably indicates that the state of injury could not have applied its own workmen's compensation act if it had chosen to do so, and the case has been cited ever since in support of that proposition.

Workmen's compensation, however, is not a field to which the public acts provision of the full faith and credit clause should ever have been applied. This provision has usually been confined to three types of cases: where the formm has no substantial contact with the case ${ }_{21}^{21}$ where the interest of the forum is slight in comparison with that of the dominant state $;^{22}$ and where the interest of the forum is substantial, but the need for uniform treatment of the members of an association outweighs the policy of respecting the forum's interest. ${ }^{23}$ Workmen's compensation does not fit any of these categories, although Mr. Justice Brandeis, in Clapper, thought it could be included in the second class. ${ }^{24}$

In the years following the Clapper decision, the Court has steadily retreated from its holding. The concept of exclusive legislative jurisdiction in the state of the dominant interest has given way to the idea of concurrent legislative

17. See Duskin v. Pennsylvania-Central Airlines Corp., 167 F.2d 727 (6th Cir. 1948).

18. U.S. Cosst. amend. XIV, $\S 1$. Although the due process clause has been argued in the workmen's compensation cases, no Supreme Court decision has restricted the extraterritorial application of a state compensation act on this ground. The argument of due process was made unsuccessfully in Alaska Packers' Ass'n y. Industrial Acc. Comm'n, 294 U.S. 532 (1935). In Cardillo v. Liberty Mut. Ins. Co., 330 U.S. 469, 476 (1947), application of the District of Columbia workmen's compensation act to an injury suffered in Virginia by an employee whose principal employment was in Virginia was held not to violate due process of law.

19. U.S. Const. art. IV, § 1 .

20. 286 U.S. 145 (1932).

21. Such a case is not likely to arise in practice. The forum may have a policy against enforcing the statute of a sister state but is not apt to apply it unless it has some more substantial contact.

22. First Nat'l Bank v. United Airlines, 342 U.S. 396 (1952); Hughes v. Fetter, 341 U.S. 609 (1951).

23. Order of United Commercial Travelers v. Wolfe, 331 U.S. 586 (1947) ; Sovereign Camp v. Bolin, 305 U.S. 66 (1938).

24. 286 U.S. $145,156-59$ (1932). 
jurisdiction in each state having a substantial interest..25 In Pacific Employers Ins. Co. v. Industrial Acc. Comm'n, ${ }^{26}$ the Court upheld the power of the state of injury to apply its own statute in a factual situation indistinguishable from the Clapper case. And the final blow to the doctrine of exclusive legislative jurisdiction came in Carroll v. Lanza ${ }^{27}$ where the state of injury was permitted to apply its own tort law although the plaintiff was covered by the compensation act of the state of the contract. Mr. Justice Frankfurter, concurring, pointed out that this holding, in effect, overruled the Clapper case. The majority was content to state that the Pacific Employers case "departed" from the Clapper decision. Even before Carroll v. Lanza, a distinguished authority took the position that a state could apply its workmen's compensation act whenever it had a substantial interest, unhampered by either the due process or full faith and credit clause. ${ }^{28}$ Since Carroll v. Lanza, the correctness of this position is open to little doubt.

\section{OVERLAPPING JURISDICTION}

The foregoing discussion reveals a confused pattern of overlapping jurisdiction and conflicting choice-of-law rules, with the United States Supreme Court almost completely abdicating its normal function of minimizing the conflict of state rules. ${ }^{29}$ Sometimes, the employee is caught without a right to compensation under the law of any state. ${ }^{30}$ More often, he has a choice of filing his claim in any one of two or more jurisdictions. The employer may have to face claims in a number of states and has the problem of obtaining sufficient insurance protection. ${ }^{31}$

25. 2 LARSoN $\S 86.20$. Larson's black-letter rule is stated in terms directly contradicting the Clapper case.

26. 306 U.S. 493 (1939).

27. 349 U.S. 408 (1955). There has been extensive re-examination of the constitutional problem since Carroll v. Lanza. Stone, The Forum's Policy and the Defense of Full Faith and Credit to Workmen's Compensaition Acts, 41 Iowa L. Rev. 558 (1956); Langschmidt, Choice of Law in Worknen's Compensation, 24 TENN. L. REv. 323 (1956); Hogan, supra note 1; Clark, Work-Injuries and the Constitution: Carroll v. Lanza, 1956 WASH. U.L.Q. 320.

Good discussions of the constitutional problems as it stood before Carroll v. Lanza are found in 2 Larson \$ 86; Wellen, Workmen's Compensation Law, Confict of Lawes and the Constitution, 55 W. VA. L. REv. 131, 233 (1952).

28. 2 LARSON $\S 86$.

29. The undesirability of the existing situation is emphasized by Cowan, supra note 8 , at 921 . See 2 LARson $\$ 86.50$ for references to "virtual withdrawal" of the Supreme Court and the "undisciplined jungle" of state rules.

30. 2 id. \$ 87.24. In Frankel Carbon \& Ribbon Co. v. Aaron, 1.13 Colo. 429, 158 P.2d 929 (1945), the Colorado court denied compensation to the dependents of an employee who was killed in Washington under circumstances where it was quite doubtful if the Washington compensation act would apply. See text at note 67 infra.

31. Private insurance companies are apparently willing to write policies which will cover the employer's possible liability under the laws of two or more states. See Allen v. Industrial Comm'n, 110 Utah 328, 340, 172 P.2d 669, 675 (1946) (dissenting opinion of 
The existence of overlapping jurisdiction raises the problem of overlapping awards. An employee who has received an award in one state may file an additional claim in a second state under its compensation act. It is now generally agreed that, if an award is recovered in the second state, the amount of the first award must be deducted and the employer only required to pay the excess. ${ }^{32}$ Thus, the practical reason for bringing a second proceeding is to secure the additional benefits which may be available in the higher compensation states, the employee having originally made the mistake of applying in a jurisdiction with a lower scale of benefits. Under some circumstances, the award in the first state is res judicata and bars any additional recovery in other states. ${ }^{33}$ Othertimes, additional recovery is permissible, particularly when the award in the first state is, in terms, without prejudice to the right to proceed elsewhere. ${ }^{34} \mathrm{~A}$ distinct problem arises when the employee who has recovered an award of compensation in one state brings a tort action against a third person in a second state for the same injury. This situation is not covered clearly by any decision of the United States Supreme Court. Some cases allow recovery, permitting the plaintiff in the tort action full damages without deduction of the amount of the compensation award. ${ }^{35}$

\section{Proposed Solutions}

Numerous solutions to the problem of confused and overlapping jurisdiction have been proposed or adopted. Among these, three are especially noteworthy-interstate compacts, uniform choice-of-law acts and reciprocal exemption statutes. Before analyzing these proposals in detail, the basic policies which underlie the willingness of the states to extend or restrict the extraterritorial application of their compensation acts should be considered.

The two principal interests requiring protection are the social interest in

Wolfe, J.). The problem may be more difficult when the employer elects to come under a state compensation fund.

32. 2 LARSON $\$ 85.70$ points out that there are certain exceptional situations in which double recovery has been allowed.

33. Magnolia Petroleum Co. v. Hunt, 320 U.S. 430 (1943).

34. See Industrial Comm'n v. McCartin, 330 U.S. 622 (1947).

35. Betts v. Southern Ry., 71 F.2d 787 (4th Cir. 1934) (recovery for wrongful death in federal court in North Carolina under Virginia wrongful death statute after compensation award granted in North Carolina-recovery inures to benefit of insurance carrier to the extent of its compensation payment); Drake v. Hodges, 114 Colo. 10, 161 P.2d 338 (1945) (widow recovered maximum damages for wrongful death in Colorado after receiving workmen's compensation in Wyoming and agreeing to reimburse the Wyoming compensation fund out of the recovery in the tort action). No double recovery actually occurs in either case because of the reimbursement agreements. See REsTATEMENT, Confuict of Laws $\S 401$ (Supp. 1948), and the criticism of this section in Ceneathans, Goodrich, Griswold \& Reese, Conflict of Laws 482 n.3 (4th ed. 1957). Compare Magnolia Petroleum Co. v. Hunt, 320 U.S. 430 (1943). 
worker welfare and the social interest in taxpayer welfare. ${ }^{36}$ Protection of the first requires that the employee should be compensated for his injury. The second is promoted by insuring that the injured employee does not become a public charge. ${ }^{3 \pi}$ Both interests are advanced by the policy of requiring employers to bear the cost of compensating workers injured in the course of their employment. Realistically, the cost of the necessary insurance against liability will be treated as a business charge which will be passed along to the ultimate consumer. And the consumer and the taxpayer are not always the same individual, particularly in the interstate situation. For example, an employee injured in California might become a public charge on the taxpayers of that state. ${ }^{38}$ If the employee recovers compensation and the employer carries insurance. the cost may very well be allocated to consumers of the employer's product throughout the United States. Thus, the interest of California in protecting its taxpayers differs from the usual policy of throwing the cost of worker injuries on society as a whole.

Clearly, a state's interest in insuring that its own domiciliaries are compensated for injuries is quite different from its interest in securing compensation for nonresidents who are injured while temporarily employed in the state. With respect to the first group, the primary consideration is worker welfare. The state's interest extends not only to compensation for the worker but to compensation at the highest level consistent with its own policy. A high compensation state should not cede jurisdiction to a lower compensation state when its residents are injured there. ${ }^{39}$ On the other hand, a high compensation state does not have nearly so great an interest in nonresidents who happen to be injured within its borders. Its concern runs no further than to prevent such workers from becoming a public charge. If the state of injury can be reasonably assured that such transient workers are actually covered by the compensation laws of their home states, it can well afford to cede jurisdiction to those states. The level of compensation in all states is high enough to make it reasonably certain that an employee who recovers compensation in one state will not become a public charge in another.

From this discussion, the general proposition arises that the state of the worker's residence has the dominant interest and the state of injury only a minor interest. Undoubtedly, this consideration underlay Mr. Justice Bran-

36. The most complete judicial treatment of the interests involved is found in the dissenting opinion of Mr. Justice Frankfurter in Carroll v. Lanza, 349 U.S. 408, 419-21 (1955); see also Cowan, supra note 8.

37. The "public charge" aspect is implicit in Pacific Employers Ins. Co. v. Industrial Acc. Comm'n, 306 U.S. 493 (1939). Some discussions of the problem overemphasize this point and fail to give sufficient weight to the social interest in the protection of workers. The state's interest goes far beyond insuring that the worker does not have to be supported by its taxpayers.

38. Ibid.

39. Larson points out that some states impose a $\$ 6,000$ limit on total permanent disability, while in other states having no limits the recovery could conceivably exceed $\$ 100,000.2$ LaRson $\$ 84.10$. 
deis's treatment of the Clapper case. However, his attempt to solve the problem in terms of exclusive jurisdiction in the state of the dominant interest has now broken down, since the Supreme Court has recognized that the interest of the state of injury, although minor, is nevertheless sufficient to justify extraterritorial application of the compensation act of that state. ${ }^{40}$ But the Brandeis idea is still of importance and can be given practical effect if the state of the lesser interest is willing to cede jurisdiction in order to bring about a more workable solution to the problem of overlapping jurisdiction without sacrifice of its own really important interests.

Another point that seems clear is that the domicile of the worker now emerges as the most important single contact. Why then has this factor been so largely neglected in the actual decisions, as well as in the statutes? The result may be traced to the traditional contract or tort approach, which throws the emphasis on the place the contract was made or the injury sustained. Another explanation may be the distrust of the domicile concept, which requires proof of a subjective nature. ${ }^{41}$ A state's real interest is in its genuine permanent residents, not in those transients who may claim a domicile by virtue of the simple statement that they intend to make their homes there. This uncertainty of proof may make it desirable to subordinate domicile as a contact point to the place of making the contract, location of the principal employment and the place of injury.

Nor should jurisdiction be based on domicile alone. Apart from the difficulty of proof, the practical objection arises that the state will rarely have judicial jurisdiction over the employer when the domicile of the employee is the only contact point. The state might not be in a position to apply its compensation act even if it wished to do so. For this reason, perhaps, Cowan bases jurisdiction on domicile only when the employer's business is localized in the forum and judicial jurisdiction is thus assured. ${ }^{42}$

Currently, the discussion seems to center about the allocation of jurisdiction between the "home state" and the state of injury. "Home state" is sometimes defined as the state where the contract of employment is made and sometimes as the state where the principal employment is located. Some reciprocal statutes use these two contact points in the alternative as bases for extraterritorial extension of the compensation act.

\section{INTERSTATE COMPACTS}

Several years ago, the suggestion was made that interstate compacts might be used to solve the problem of overlapping jurisdiction in the compensation field. ${ }^{43}$ This device seems to have been employed successfully in Europe,

40. Pacific Employers Ins. Co. v. Industrial Acc. Comm'n, 306 U.S. 493 (1939).

41. Mr. Justice Rutledge, dissenting in Williams v. North Carolina, 325 U.S. 226, 245 (1945), speaks of a concept "as variable and amorphous as 'domicil" and attacks its utility as a basis for judicial jurisdiction in divorce.

42. Cowan, supra note 8; see 2 LARSON $\$ 87.50$.

43. Dwan, Workmen's Compensation and the Conflict of Laws, 11 Minn. L. Rev. 329 (1927). 
where a compact between England and France governs injuries to workers. ${ }^{44}$ Thus far, no actual compacts on workmen's compensation are in effect in the United States. Our experience of the past thirty years with interstate compacts indicates that many practical difficulties militate against their use in situations in which statutes can be constitutionally employed. ${ }^{45}$ Interstate compacts are cumbersome and require extensive negotiations. In each compact, one state has to convince the other of the desirability of the particular approach which it wishes to follow. Once the compact is in effect, it is inelastic and adjustments are difficult. If a state has agreed to a policy which it later considers disadvantageous, the compact hinders any readjustment or improvement of the situation.

A fresh impetus has been given to the use of interstate compacts in the compensation field by the recent action of Oregon. ${ }^{46}$ In 1955 , the legislature authorized the state Industrial Accident Commission to enter into such compacts with the workmen's compensation agencies of other states in situations in which the employment contract is in one state and the injury is received in another state and in other cases where the reach of jurisdiction of the two states is in dispute. This statute obviously contemplates reciprocal exemption like that provided in the reciprocal exemption statutes, but with the extent of the exemption to be determined by the terms of the compact.

\section{UNIFORM CHOICE-OF-LAW ACTS}

Two proposals have been put forward for the use of uniform state laws governing the extraterritorial application of workmen's compensation acts. These are the Model Workmen's Compensation Law ${ }^{47}$ and a uniform choiceof-law act, drafted by Cowan. ${ }^{48}$

The Model Workmen's Compensation Law is not designed as a uniform act in the usual sense of that phrase but is suggested as a model which may be helpful to states in drafting or revising their statutes. The extraterritorial provisions of this act are found in section six. The connecting factor is the

44. This compact was originally attached as a schedule to the Workmen's Compensation (Anglo-French Convention) Act, 1909, 9 Edw. 7, c. 16.

45. It is generally felt that the experience of Colorado with the seven-state Colorado River Compact has not been a happy one. This agreement, made many years ago, overestimated the available flow of the Colorado River and has been a source of difficulty ever since. Boulder Canyon Project Act, 45 Stat. 1058 (1928), 43 U.S.C. \& 617c (1952), stated that no water rights could be claimed or initiated until ratified by California and five of six other western states-Arizona, Colorado, Nevada, New Mexico, Utah and Wyoming. It was subsequently ratified. Colorado has passed an act implementing its duties thereunder with regard to allocation of water between the upper and lower basin states. Colo. Rev. Stat. Ans. § 148-8-1 to -6 (Supp. 1957).

46. Ore. Rev. Stat. § 656.126(4) (1955).

47. Model Workmen's Compensation Law $\S 6$ (1955), prepared by the U.S. Dep't of Labor, released Nov. 1955, BNA Daily Lab. Rep. Special Supp. No. 33 (Dec. 6, 1955).

48. Cowan, supra note 8 , at $922-24$. 
carrying on of employment in the state, and the act applies regardless of the place of injury. The statutory definition of "carrying on employment" includes all cases where the contract is made within the state as well as those in which the contract is made elsewhere for employment within the state. The problem of overlapping awards is handled by a provision amounting to an election of remedies. When the claimant has been awarded compensation or has entered into an agreement for compensation approved by proper authority in another state, he comes exclusively under the coverage of the compensation law of that state and is entitled to no benefits under the compensation act of the forum. No direct provision bars a tort action in the forum, however.

The Cowan proposal for a uniform act is much more complex and is based on the multiplication-of-contacts theory. The statute of the forum applies in three distinct situations: where the forum is the state of domicile of the employee and also the place where the employer's business is localized; where any three of the five important connecting factors are present in the forum; and where the employee is not otherwise covered by any compensation act and the employer's business is localized within the state.

The five contacts relevant to the second situation are roughly the same as those previously mentioned in this Article. The phrase "business localized within the state"40 is arbitrarily defined: if sixty per cent of the employees are normally employed within its limits, a state becomes the state of localization. If no such state exists, the employer is considered to have a business localized in every state in which he is authorized to do business. The employee's "principal place of work" is also given an arbitrary definition: the state where the employee has actually worked, or has contracted to work, for a period of nine months or more.

An example may show how this rather complex scheme works out in practice. Suppose that Texas has adopted the proposed act. An employee who has been injured in Texas wishes to know whether his claim can be filed in that state. The fact that Texas is the place of injury is not enough; further contacts must be sought. The first questions are where the employee is domiciled, whether the employer has qualified to do business in Texas and whether the employer's principal focus is outside the state. If Texas domicile coincides with business focus in Texas, no further inquiry is necessary. The employee is covered by the Texas act. If either of these factors is missing, attention must be given to the five contact points, any three of which must be present. Thus, if Texas is the domicile of the employee, the state of injury and the state where the employee's principal services were to be rendered, the employee again is covered although no business focus is in the state and the contract of employment was made outside Texas.

Section (c) of the Cowan proposal is a "catch-all" provision, designed to pick up the case of any employee whose claim might otherwise be lost in the

49. In this Article the term "business focus" is used as a short synonym for this phrase. 
shuffle. As previously suggested, the state of domicile has an interest in insuring that its residents do not go uncompensated, and a possibility of restrictive interpretation always exists, which might leave cases uncovered by the law of any state. Section (c) is intended to avoid that possibility.

Cowan also has a lengthy provision directed to minimizing the cases of overlapping awards. His proposed statute makes the award in the first state res judicata in the second state if a certain procedure is followed. The employer is required to file with the Commission in the first state a statement showing the principal contact points and, whenever relevant, must notify the employee that he has the election to file his claim in one of two or more states. These requirements are designed to avoid the situation apparently present in the Magnolia case, where the employee injured in Texas agreed to accept the full compensation available in that state, not knowing that he could obtain higher compensation in Louisiana..$^{50}$

Compared with the Model Workmen's Compensation Law, the Cowan proposal places great emphasis on domicile. This factor is only indirectly mentioned in the Model Law, in the general statement of intention to provide a remedy for residents of the state. Also, Cowan's phrase "business localized in the state," with its exact definition, should be compared with the wording "employer who carries on any employment in this state," found in the Model Law.

Neither of these proposals makes any attempt to solve the problem of overlapping jurisdiction, as distinct from the problem of overlapping awards. The assumption seems to be that broad extraterritorial coverage is desirable and that the resulting overlapping jurisdiction is a more or less necessary evil. What the two proposals do accomplish is to bring some degree of uniformity into the conflicting choice-of-law rules found under existing law. But the reciprocal exemption statutes offer a superior solution to overlapping jurisdiction. Their operation challenges the continuing existence of this problem.

\section{Reciprocal Exemption Statutes}

Reciprocal exemption statutes are based on the theory that the state of injury, having the lesser interest, can afford to cede jurisdiction to the state with the dominant interest, usually the state where the contract is made or where the principal employment is located. As suggested earlier, the state of the employee's domicile has the strongest interest of all, but the statutes have generally ignored this factor. In most cases, however, domicile will probably coincide with the state in which the contract is made.

50. Magnolia Petroleum Co. v. Hunt, 320 U.S. 430, 450 (1943) (dissenting opinion). No provision governs overlapping awards in the reciprocal exemption statutes. Probably, the smaller number of cases of overlapping jurisdiction in states which adopt these statutes will make the problem of overlapping awards a minor one. 
Reciprocal exemption statutes have been enacted in eleven states. ${ }^{51}$ In ten of these, provisions for extraterritorial extension of the statute of the forum are combined with provisions exempting out-of-state employers from liability, under the forum's statute, to employees temporarily working in the forum. Both types of provisions are reasonably necessary to a satisfactory scheme of reciprocal exemption. State $X$ should be willing to exempt employers who have made contracts in state $Y$ only if state $X$ can be sure that the employee who is injured in $X$ is actually covered by the compensation act of $Y$. If state $Y$ has a statute containing extension provisions, state $X$ will be satisfied on this point. Therefore, both states must have extension provisions to justify exemption and insure complete reciprocity. Of course, these extension provisions need not be in the exemption statute itself. A state may make its act applicable to injuries suffered beyond its borders by other statutory enactment or by judicial interpretation. Most states, however, seem to feel that the situation is clarified if the extension provisions are combined directly with the exemption provisions in consecutive sections of the statute.

The extension provisions are not enacted solely to secure reciprocity. When a state gives up its jurisdiction over out-of-state workers injured within its territory, it is recognizing the dominance of the state of contract or principal employment and should therefore assert its own jurisdiction in cases where it is the dominant state. A typical exemption statute is found in California:

"\$ 3600.5 ... (b) Any employee who has been hired outside of this State and his employer shall be exempted from the provisions of this division while such employee is temporarily within this State doing work for his employer if such employer has furnished workmen's compensation insurance coverage under the workmen's compensation insurance or similar laws of a state other than California, so as to cover such employee's employment while in this State; provided, the extraterritorial

51. The following states combine reciprocal exemption provisions with provisions for extraterritorial extension of the statute of the forum: CAL. LAB. CODE $\$ 3600.5$; Colo. Rev. Stat. Ann. $\$ \S 81-16-1$ to -5 (Supp. 1955); Md. Ann. Code art. 101, $\$ 67(3)$ (1957) ; Mrss. Code ANn. $§ 6998-55$ (Supp. 1956) ; Nev. Rev. Stat. $\$ 616.260$ (1956); N.M. Stat. Ann. $\$ \$ 59-10-42,59-10-43$ (Supp. 1957); N.D. Rev. Code $\$ \S 65-0801$, 65-0\$02 (Supp. 1949) ; UTAH CoDE ANn. \$\$ 35-1-54, 35-1-55 (Supp. 1957) ; Wyo. CoMrP. Stat. Ann. $\$ \$ 72-301,72-302,72-313$ (Supp. 1957).

Ohio has provisions for extraterritorial extension but only when the parties have agreed that the compensation act shall apply and the agreement is filed with the Industrial Commission of Ohio. OHio Rev. Code Ann. \$ 4123.54 (Page Supp. 1957).

Rhode Island has adopted a reciprocal exemption statute which has no provision for extraterritorial extension. Public Laws of R.I. 1941, c. 1052, $\$ 1$ (amending R.I. GEN. Laws ANN. c. 300 (1938)). This omission is probably due to the fact that the Rhode Island courts had previously held that their statute applies whenever the contract is made in Rhode Island. Grinnell v. Wilkinson, 39 R.I. 447, 98 Atl. 103 (1916).

South Dakota has a broad provision for reciprocity without a direct provision for exemption. S.D. CoDE $\$ 64.0113$ (Supp. 1952).

Oregon has no reciprocal exemption statute but authorizes the State Industrial Accident Commission to enter into agreements with other states relating to conflict of jurisdictions. ORE. Rev. STAT. \& 656.126(4) (1955). 
provisions of this division are recognized in such other state and provided employers and employees who are covered in this State are likewise exempted from the application of the workmen's compensation insurance or similar laws of such other state. The benefits under the Workmen's Compensation Insurance Act or similar laws of such other state, or other remedies under such act or such laws, shall be the exclusive remedy against such employer for any injury, whether resulting in death or not, received by such employee while working for such employer in this State.

"A certificate from the duly authorized officer of the Industrial Accident Commission or similar department of another state certifying that the employer of such other state is insured therein and has provided extraterritorial coverage insuring his employees while working within this State shall be prima facie evidence that such employer carries such workmen's compensation insurance." ${ }^{2}$

The ten other states with reciprocal exemption statutes have substantially similar provisions. Several key phrases should be noted. The phrase "hired outside of this state" sets one of the limits on the class of employees exempted. If an Ohio employer sends one of his regular employees, hired under a contract made in Cleveland, to Los Angeles on a job which will require a week or so to complete, the employee meets the qualification "hired outside of this state" under the California statute. He also meets the second qualification "temporarily within this state." For the California exemption to apply, however, further qualifications must be met. The Ohio Workmen's Compensation Act must cover this employee while he is in California. The employer must carry compensation insurance covering his liability under the Ohio statute. And Ohio must have a reciprocal statute exempting California employers in the converse situation-in fact the case.

Two situations may illustrate the limits of the statute. If the Ohio employer hires an employee in Cleveland for a job which will require several months to complete and which is to be performed entirely in California, exemption from coverage under the California statute is not clear. The phrase "temporarily within this state" obviously sets some time limit on the applicability of the exemption. One may hazard a guess that this employee would not qualify for the exemption. Again, if the Ohio employer hires an employee in Los Angeles for a job which is to be performed principally in California but requires some temporary services in Ohio, this employee clearly fails to qualify for the exemption in California. Perhaps the more relevant inquiry, however, is into the applicability of the Ohio exemption. For the employee is likely to be domiciled in California.

In these illustrations, the employee may or may not be covered by the Ohio statute. If he is covered by both the Ohio and California statutes and the necessary conditions for exemption under either do not exist, a case of overlapping jurisdiction arises. Since the main purpose of exemption statutes is to prevent such overlapping, a nondomiciliary court should interpret the

52. CaL. Lab. CoDE $\S 3600.5$ (b). 
exemption provisions to apply to as many cases as possible, consistently with the express statutory limits, if assured of the employee's coverage in his domiciliary state. In this fashion, the policy of prevention of overlapping can be harmonized with preservation of the dominant state's interest in insuring that its citizens are compensated. Thus, it might be well to consider an employee to be "temporarily within this state," even though he may have been present for several months. The court in the domiciliary state, on the other hand, might be well advised to construe its exemption provision narrowly. The phrase "hired outside of this state," for example, might be interpreted to have no application to a citizen whose employment relation in the foreign jurisdiction did not exceed a job interview and the signing of a contract. More precisely, a California court considering the case of a California citizen who was interviewed and hired in Ohio for work which was to be performed in California might want to exercise jurisdiction since California is the dominant state. Conversely, the Ohio court in this circumstance would construe its "hired outside of this state" exemption to encompass nonresident employees hired in the state for work to be performed in the state of their domicile.

The statute also requires certain steps of the Ohio employer who plans to send one of his regular employees to California on a temporary job and wishes to take advantage of the California exemption. He should make sure that the Ohio statute will cover this employee while he is in California ${ }^{53}$ and that his workmen's compensation insurance will cover any liability to this employee under the Ohio act while the employee is in California, taking out additional insurance if necessary. Beyond these general precautions, more specific steps are desirable. The employer should procure a certificate from the Industrial Commission of Ohio certifying that such insurance is in effect and forward this certificate to the California Industrial Accident Commission.

A question of great importance to employers is whether the procurement of the certificate of insurance is a necessary condition to the application of the exemption. The statute itself does not so provide; it merely states that the certificate shall be prima facie evidence that the employer carries compensation insurance. Courts interpreting such provisions in exemption statutes should not raise a desirable evidentiary aid to the dignity of a necessary precondition. The area abounds in complications without the addition of unnecessary technicalities. An employer should be free to procure and produce a certificate after the injury ${ }^{54}$ or to prove coverage by any other available

53. The unusual extension provisions of the Ohio Act, Orro Rev. Cone ANN. $\$ 4123.54$ (Page Supp. 1957), render this task more difficult than necessary. Extraterritorial coverage is only granted when an agreement in writing between employer and employee to such coverage has been filed with the industrial commission.

54. The only case in which the certificate was procured and filed after the injury was State Compensation Ins. Fund v. Howington, 133 Colo. 583, 298 P.2d 963 (1956). The point directly involved in this case was the provision for the extraterritorial application of 
evidence. A distinction should be drawn between the steps an employer is legally required to take and those which it is advisable for him to take. ${ }^{65}$

\section{Extraterritorial Extension Provisions}

The theory of reciprocal exemption is that the "home state" has the dominant interest and the state of injury the minor interest. This theory is made practically effective by a statute which asserts the extraterritorial jurisdiction of the home state as well as exempts injured casual workers. Most of the statutes are drawn along these lines and contain specific extension provisions.

The California extension statute is again typical:

"\$3600.5 ... . (a) If an employee who has been hired or is regularly employed in this State receives personal injury by accident arising out of and in the course of such employment outside of this State, he, or his dependents in case of his death, shall be entitled to compensation according to the law of this State."56

This section recognizes the dominance of the home state and uses as alternative bases for extension the contact points of hiring within the state or regular employment within the state. In contrast is the language of the exemption statutes, which adopts "hiring outside of the state" as the basis without mention of the location of the regular employment. Because the interest of the dominant state may require narrow construction of the "hired outside of this state" provision in the exemption statute, the regular employment provision should be utilized for exemption as well as extension. Statutory amendment to this effect would obviate difficulties of construction and promote harmony between the elimination of overlapping jurisdiction and the recognition of the dominant state's interest in its own citizens. In other respects, the exemption and extension provisions fit together to form a consistent pattern, the forum asserting its jurisdiction whenever it is the home state and ceding jurisdiction whenever it is merely the state of injury. This cession of jurisdiction is accomplished by the clause in the reciprocal exemption statutes providing that the benefits of the statute of the other state shall be the exclusive remedy when the conditions for exemption exist.

the act of the state of hiring. Colo. Rev. Stat. Ann. $\$ 81-16-3$ (Supp. 1957). The State Compensation Fund took the position that neither the extension nor the exemption provisions of this statute took effect until the certificate had been procured and filed. On this basis, the Industrial Commission denied the claim. The Supreme Court of Colorado, however, held that both the extension and the exemption provisions took effect from the time the insurance was procured.

55. In reply to a questionnaire submitted by the authors, the Utah Industrial Commission stated definitely that the exemption is effective from the time the insurance is procured, indicating that procuring the certificate is not a condition of the exemption. The Wyoming Commission interprets the submission of a certificate as a prerequisite to exemption.

56. Cal. LaB. Code $\S 3600.5$ 
One problem that has concerned the legislatures relates to the time element. While the exemption provisions are limited to employees temporarily within the state, no corresponding limitation is to be found in the extension provisions. It is probably undesirable to extend the extraterritorial jurisdiction of the home state to employees working permanently outside the state. Apparently recognizing this problem, Mississippi specifically provides an exception in the case of employees whose departure from the state is caused by a permanent assignment or transfer. ${ }^{57}$ Some other states employ a sixmonth clause: after any employee has been absent from the state for more than six months, he is no longer subject to the local act unless the employer files a certificate with the Industrial Commission extending his liability. ${ }^{58}$

\section{Experience With the Statutes}

Only a few cases interpreting reciprocal exemption statutes have reached the appellate courts. One of these cases is directly concerned with the exemption provisions, while the others determine the extent of extraterritorial coverage under the extension provisions.

In LaDew $v$. LaBorde, ${ }^{59}$ a resident of Louisiana made a contract of employment with an employer living in Texas whose business extended over Texas, Louisiana and Mississippi. The contract was made in Texas, and the principal place of employment was Louisiana. The employee suffered a heart attack in Mississippi, where he was working on a job which was apparently temporary. However, the employer had obtained compensation insurance under the Mississippi law for coverage of employees in that state and had paid premiums which were based on the wages of the particular employee while working in Mississippi. The employer claimed exemption under the provisions of the Mississippi statute, ${ }^{60}$ since the employee was hired outside of Mississippi. The court held that the exemption did not apply because Louisiana had no reciprocal statute. No evidence before the court showed that the employer carried compensation insurance on this particular employee

57. MIss. Code AnN. $\$ 6998-55$ (b) (Supp. 1956). This clause was construed in Winborn v. R. B. Tyler Co., 94 So. 2d 340 (Miss. 1957). The Supreme Court of Mississippi gave a restrictive interpretation to the word "permanent," applying the Mississippi statute to an injury in Louisiana where all work in Mississippi had ceased and the employee was transferred to a project of limited duration in Louisiana. See also Wyo. Consp. Stat. Ann. \& 72-301 (Supp. 1957) for similar provision.

58. Colo. Rev. Stat. Ann. \$ 81-16-3 (Supp. 1957) ; Miss. Code Ann. \$\$ 6998-55(a), (b) (Supp. 1956) (not applicable in case of a permanent assignment or transfer) ; N.M. Stat. ANN. \$ 59-10-42 (Supp. 1957) ; UTA CODE ANN. \$ 35-1-54 (Sưpp. 1957); Wyo. Comp. Stat. Ann. $\$ 72-301$ (Supp. 1957).

Maryland, which does not have the six-month clause, provides for extraterritorial extension in the case of "casual, occasional or incidental employment." MD. ANN. CoDE art. 101, \& 67(3) (1957).

59. 216 Miss. 598,63 So. $2 \mathrm{~d}$ 56, modified on rehearing, 216 Miss. 606,63 So. $2 \mathrm{~d}$ 825 (1953).

60. Miss. Code AnN. $\$ 6998-55$ (c) (Supp. 1956). 
in Louisiana, nor was it even clear that the Louisiana compensation act would cover him extraterritorially. Thus, even if Louisiana had a reciprocal act, the employer might not have been exempt. It may be noted that this is a true choice-of-law case, for Mississippi is the only state which, apart from statute, affirmatively enforces the compensation acts of other states, ${ }^{61}$ and the employer claimed that the Louisiana rather than the Mississippi act should apply.

The Utah and Colorado cases dealing with the extension provisions show how the extraterritorial jurisdiction of the "home state" has been enlarged. In Allen v. Industrial Comm' $n$, ${ }^{62}$ an employee domiciled and hired in Utah for a position involving work in Nevada only was injured in the latter state. The Utah court held that its own statute applied. The statute itself is clear enough, since it extends to situations in which Utah is either the state of hiring or the state where the principal services were to be rendered. ${ }^{83}$ Before the enactment of the reciprocal act, however, Utah used the concept of "location of the employment status," interpreted as meaning the state where the principal services were to be rendered. ${ }^{84}$ The employer relied on the earlier cases as an indication that the Utah statute did not cover a situation where all services were to be performed in Nevada. The court pointed out the changes made by the reciprocal statute.

A concurring opinion agreed on the interpretation but had some doubt about its advisability. So far as the Allen case is concerned, Utah was surely the state with the dominant governmental interest, since the domiciles of both employee and employer, as well as the employer's headquarters, were in that state. The concurring opinion pointed out that if other states had similar statutes, overlapping jurisdiction would result. This conclusion is incorrect, for it is the existence of similar statutes which prevents overlapping jurisdiction. At the time of decision such a problem was present, but since the adoption of the reciprocal act by Nevada in $1955,{ }^{65}$ the Utah employer would be exempt in Nevada if he complied with the statute in a case like Allen $v$. Industrial Comm'n.

The Colorado reciprocal act received a severe blow in Frankel Carbon \& Ribbon Co. v. Aaron ${ }^{68}$ an unfortunate decision which is probably no longer law. The situation was similar to that in the Allen case. The employee was

61. Orleans Dredging Co. v. Frazie, 173 Miss. 882, 161 So. 699 (1935); Floyd v. Vicksburg Cooperage Co., 156 Miss. 567, 126 So. 395 (1930); 2 LARson $§ 84.20$.

62. 110 Utah 328, 172 P.2d 669 (1946).

63. UTAH Code ANN. § 35-1-54 (Supp. 1957).

64. Fay v. Industrial Comm'n, 100 Utah 542, 114 P.2d 508 (1941). The Fay case shows the undesirability of the phrase "location of the employment status." The earlier Utah decisions treat this phrase as synonymous with "location of the principal employment," whereas in Val Blatz Brewing Co. v. Industrial Comm'n, 201 Wis. 474, 230 N.W. 622 (1930), the court suggested that the employment status might exist in a state where no services were to be rendered.

65. Nev. Rev. Stat. § 616.260 (1956).

66. 113 Colo. 429,158 P.2d 929 (1945). 
domiciled and hired in Colorado as a salesman whose territory lay outside of the state. About two years later, he was injured and died in Washington, a state which did not have a reciprocal statute. Before the enactment of the reciprocal act, the Colorado workmen's compensation law would not have extended to this death, since the "judicial rule" required that substantial services be rendered in Colorado. ${ }^{67}$ This requirement was abolished by the reciprocal act. A holding for the defendant company would still have been proper under that act, because the injury took place more than six months after the employment began and no certificate of time extension had been filed by the employer. ${ }^{68}$ Ignoring this aspect, the court held for the defendant on the ground that neither the extension nor exemption provisions had any application when the other state involved had no reciprocal statute. The holding on the exemption provisions is clearly correct, but the statute contains no such express requirement for the extension provisions.

In State Compensation Fund $v$. Howington, ${ }^{60}$ a similar situation arose, but the other state, Utah, had a reciprocal statute ${ }^{70}$ and the employee was injured less than six months from the date of employment. These facts distinguish the Aaron case, and the court's decision in favor of the employee, Howington, could be justified on these grounds alone. But the court went further and stated that the Aaron case was overruled "as far as inconsistent with the present holding." 71 Of course, the two cases are not inconsistent at all, and the only reason for the dictum about overruling Aaron must have been a desire to express dissatisfaction with its fundamental theory. Howington may thus be regarded as persuasive authority for application of the extension provisions of the Colorado reciprocal act in cases where the other state involved does not have a similar statute.

In Denver Truck E.rchange v. Perryman, ${ }^{72}$ the court had some difficulty in determining where the "contract" was made. Perryman was killed in Kansas while driving the defendant's truck. His immediate employer clearly made the employment contract with him in Michigan. In terms, the Colorado statute would not cover this casse, since the contract was not made in Colorado and the principal services were not to be rendered there. The Industrial Commission held for the claimant on the theory that a contract between the immediate employer and the Truck Exchange made the latter a "principal contractor" and, as such, liable for injuries to employees of its "sub-contractor."73 The supreme court conceded that this strained interpretation of the

67. United States Fidelity \& Guaranty Co. v. Industrial Comm'n, 99 Colo. 280,61 P.2d 1033 (1936), 22 Rocky Mr. L. REv. 77.

68. This distinction is pointed out in State Compensation Fund v. Howington, 133 Colo. 583, 298 P.2d 963 (1956).

69. Ibid.

70. UTAH Code ANn. § 35-1-55 (Supp. 1957).

71. 133 Colo. at 594,298 P.2d at 969.

72. 134 Colo. 586, 307 P.2d 805 (1957).

73. Id. at 595-96, 307 P.2d at 811-12. 
principal contractor provision ${ }^{74}$ of the Colorado compensation act was sustained by earlier cases where all of the facts occurred in Colorado. It refused to extend the doctrine, however, to cases of injury or death outside Colorado. Moreover, the court decided that the contract between the subcontractor and the Truck Exchange was made in Michigan. Unfortunately, the court proceeded to resuscitate the "judicial rule" which it had officially buried in the Howington case. It stated that two out of three conditions must concur to sustain jurisdiction-an employment contract made in Colorado, employment in Colorado or substantial services rendered in Colorado. But only the first or second condition is required under the express terms of the extension provisions of the reciprocal act.

The experience of industrial commissions has been fairly extensive in some states but quite sketchy in others, as indicated by the replies to a questionnaire sent by the authors to the commissions of all states having reciprocal statutes. These replies indicate that employers are not sufficiently informed about the statutes and so fail to take full advantage of the exemption provisions. California notes an increasing awareness in the past year, evidenced by a greater number of requests for exemption. The California Commission suggests that the phrase "temporarily within the state" should be more exactly defined to meet this growing demand. And the South Dakota Commission thinks its act should be amended to conform more closely to the pattern found in other states. Such responses suggest that the statutes are beginning to attain the effect they seek-a clear idea of the extent of coverage and an awareness that the statutes of the enacting states are mutually interdependent.

\section{Home State v. State of Injury}

Recent discussions of the problem of overlapping jurisdiction in the compensation field indicate the existence of two conflicting schools of thought. One group favors the dominance of the "home state," as the one with the most substantial governmental interest, while the other insists on preserving the jurisdiction of the state of injury. The first group favors the adoption of reciprocal exemption statutes. The latter wishes to retain the conflicting jurisdiction of the state of injury and suggests leaving the law as it now stands or adopting a uniform choice-of-law act which would recognize the concurrent jurisdiction of both states. This clash has been particularly noticeable in the discussions of the American Bar Association's Special Committee on Extraterritoriality ${ }^{75}$ and has so far prevented any agreement on the type of uniform extraterritorial statute which the Committee is prepared to recommend or the basic principles on which that statute should be predicated.

74. Colo. Rev. Stat. Ann. § 81-9-1 (Supp. 1957).

75. U.S. Bureau of Labor Standards, Dep't of Labor, Bull. No. 186, Workaren's Compensation Problems, IAilBC Proceedings 175 (1955), contains the report of the Special Committee. 
Up to the present time, many of the large industrial states have been reluctant to adopt reciprocal exemption statutes. Some of these states have higher compensation rates than those found in other jurisdictions. Quite understandably, a high compensation state will be unwilling to cede jurisdiction over its own residents injured in that state. ${ }^{76}$ Some of these states, however, may have lost sight of the difference between the interest they have in such cases and in those involving the injury of nonresidents casually present in the state. The social interest in individual welfare does not extend to such nonresidents to a degree justifying the higher compensation states' rejection of a reasonable compromise which will work out to the best advantage of all states.

The real solution lies in the adoption by higher compensation states of reciprocal exemption statutes which grant the exemption only in the case of nonresident employees injured in the forum, while denying it in the case of its own residents. ${ }^{77}$ The state's interest in preventing an injured workman from becoming a public charge is sufficiently protected by the assurance that the workman is covered in some state, and it is only upon this condition that the exemption is granted at all. This proposal recognizes the legitimate claim of a state to insure maximum compensation to its own residents and, at the same time, indicates a workable compromise between the two conflicting schools.

A possible objection might arise from the fear that states with reciprocal exemption statutes in the present form might regard a statute reserving jurisdiction over residents as not furnishing the required degree of reciprocity. This fear will prove unfounded if judges recognize the true character of the governmental interests involved and give a liberal meaning to the phrase "reciprocal recognition." If any court were to hold that the proposed statute did not qualify, the legislature of that state could easily add a provision to its own statute reserving jurisdiction in the case of residents. Moreover, if existing statutes are, as suggested earlier, construed in a manner promoting recognition of the interest of the dominant state, this problem should not even arise.

\section{Comparative Analysis of the Proposals}

Three proposals for reducing the conflict of jurisdiction in workmen's compensation cases involving two or more states have been described. Each of these proposals has some merit. Each will no doubt provoke criticism, and substantial opposition may confront the adoption of any one of them. A comparison of the operation of these proposals may be wise to show how each handles the problem.

76. 2 LARSoN $\S 86.33$ stresses the interest of the state of residence. A table showing the varying rates of compensation is found in id. at 522 .

77. North Dakota limits the exemption to residents of other states. N.D. REv. CoDE $\S 65-0802$ (Supp. 1949). 
The reciprocal statutes establish jurisdiction in the forum when it is the state of the contract, the state of principal employment or the state of injury. The Uniform Choice-of-Law Act, proposed by Cowan, uses a more complex method of asserting jurisdiction where certain named contacts or combinations of contacts are present in the forum. The interstate compacts assume that the existing choice-of-law rules, which vary from state to state, may be modified by negotiation between any two or more states entering into a compact in such a way as to minimize the conflict of jurisdiction.

The method used in the reciprocal exemption statutes is the simplest of the three. The more complex provisions of the Cowan proposal seem to be in line with the sound approach of basing jurisdiction on the weighing of contacts. There is some doubt, however, of the advisability of accomplishing this end by legislative enactment instead of leaving the process of evaluation to the courts. The very complexity of the process makes it less likely that the legislatures of any great number of states would be willing to accept the proposal in its exact form. That this difficulty is less apt to be encountered in the pattern of the reciprocal exemption statutes is indicated by their adoption in eleven jurisdictions. The attempt to solve the problem of jurisdiction by negotiation between states, culminating in interstate compacts, involves the difficulties already discussed-difficulties which are likely to delay and disturb the objective of uniformity and limitation of jurisdictional conflicts.

Two considerations should govern the choice between the three proposals. The one selected must be likely to reduce significantly the problems of conflicting jurisdiction. And it must have features to commend it to the state legislatures. Both considerations point to the adoption of reciprocal exemption statutes. These statutes seem better designed for the purpose desired, and their existence in so many states provides a workable point of departure for their enactment in other states. Nationwide adoption of reciprocal exemption statutes, accordingly, seems the best solution of the difficulties resulting from overlapping jurisdiction and the confused state of the present choice-of-law rules governing workmen's compensation. 